CrossMark \&lick for updates

Cite this: Dalton Trans., 2016, 45, 7391

Received 23rd October 2015, Accepted 15th March 2016

DOI: $10.1039 / \mathrm{c} 5 \mathrm{dt} 04176 \mathrm{~g}$

www.rsc.org/dalton

\section{Characterization of decavanadate and decaniobate solutions by Raman spectroscopy $\uparrow$}

\author{
Manuel Aureliano, ${ }^{\star a, b}$ C. André Ohlin, ${ }^{c}$ Michele O. Vieira, ${ }^{b}$ M. Paula M. Marques, ${ }^{b, d}$ \\ William H. Casey ${ }^{e}$ and Luís A. E. Batista de Carvalho ${ }^{b}$
}

\section{Introduction}

Decavanadate $\left(\left[\mathrm{V}_{10} \mathrm{O}_{28}{ }^{6-}\right], \mathrm{V}_{10}\right)$ is a member of a larger family of Group V and VI polyoxoanions commonly known as polyoxometalates (POMs). POMs have been found to have anti-diabetic, -bacterial, -protozoal, -viral and -cancer activities, which have sparked interest in their use as bio-inorganic drugs. ${ }^{1-4}$ Decavanadate is a homoleptic isopolyoxovanadate that interacts with high affinity with several proteins such as myosin, actin, and $\mathrm{Ca}^{2+}$-ATPase, thus affecting a range of cellular processes, including calcium homeostasis, muscle contraction, cytoskeleton dynamics and mitochondrial oxygen consumption..$^{4-11}$ Furthermore, the antidiabetic, anti-virus, anti-bacterial and anti-tumor activities of $\mathrm{V}_{10}$ and vanadate compounds are attracting increasing interest. ${ }^{12-18}$ Decavanadate also exhibits insulin-mimetic behavior, and it was shown that, upon incubation with decavanadate, rat adipocytes accumulate much more glucose than with well-established mimetic agents such as BMOV. ${ }^{18}$ Decavanadate is in many

${ }^{a}$ FCT and CCmar, University of Algarve, 8005-139 Faro, Portugal.

E-mail: maalves@ualg.pt; Fax: +351 289 800066; Tel: +351 289800905

${ }^{b}$ Unidade de I\&D Quimica-Física Molecular, Department of Chemistry, University of Coimbra, Portugal

${ }^{c}$ School of Chemistry, Monash University, Clayton, Vic 3800, Australia

${ }^{d}$ Department of Life Sciences, University of Coimbra, 3004-535 Coimbra, Portugal

${ }^{e}$ Department of Chemistry, University of California, Davis, California 95616, USA

$\dagger$ Electronic supplementary information (ESI) available. See DOI: 10.1039/ c5dt04176g cases likely a pro-drug, inducing anti-diabetic activity through peroxovanadate production. ${ }^{17}$ On the other hand, in vivo exposure to decavanadate, in comparison with vanadate, affects differently subcellular metal distribution, antioxidant enzyme activities, lipid peroxidation and tissue damage in several organs. ${ }^{4,9,10,19}$ Recently, decavanadate has also found application in other processes such as aerobic oxidation of starch, solar-driven photocatalysis and protein crystallography. ${ }^{20-22}$

Depending on factors such as vanadate concentration, $\mathrm{pH}$ and ionic strength, different vanadate oligomeric species can occur simultaneously in vanadium(v) solutions, including monomeric $\left(\mathrm{V}_{1},\left[\mathrm{VO}_{4}\right]^{3-}\right.$ at high $\left.\mathrm{pH}\right)$, dimeric $\left(\mathrm{V}_{2},\left[\mathrm{~V}_{2} \mathrm{O}_{7}\right]^{4-}\right)$, tetrameric $\left(\mathrm{V}_{4},\left[\mathrm{~V}_{4} \mathrm{O}_{12}\right]^{4-}\right.$ and $\left.\left[\mathrm{V}_{4} \mathrm{O}_{13}\right]^{6-}\right)$, and pentameric $\left(\mathrm{V}_{5}\right.$, $\left[\mathrm{V}_{5} \mathrm{O}_{15}\right]^{5-}$ ) vanadates. ${ }^{4,23,24}$ These ortho and metavanadate species are comprised of tetrahedral vanadate units. In addition to them, the decavanadate ion, $\mathrm{V}_{10}$, which consists of octahedral vanadate units, also occurs in solution. Its presence is easily detected due to the strong orange-yellow colour of $\mathrm{V}_{10}$ compared with the colourless ortho and metavanadates.

Whereas an equilibrium between the ortho and metavanadate species is achieved on the millisecond-to-second time scale in neutral and alkaline aqueous solutions, $\mathrm{V}_{10}$ interconversion with the other vanadate oligomers occurs on a considerably longer time scale. The disappearance of the decamer follows a first-order kinetic process and can be easily followed by UV/Vis spectroscopy by recording the absorption band at $400 \mathrm{~nm}$ as a function of time. ${ }^{4-6}$ In addition, $\mathrm{V}_{10}$ decompo- 
sition may be prevented through binding to specific proteins, which apparently retard dissociation. Increases in the half-life from 5 to 17 hours in the presence of sarcoplasmic reticulum vesicles, and to 27 hours in the presence of actin were found at room temperature and $\mathrm{pH} 7.0,{ }^{25}$ whereas no effects were observed with myosin, even though it is known to have a highaffinity $\mathrm{V}_{10}$-binding site. ${ }^{26}$

Decavanadate was observed to induce protein cysteine oxidation and vanadyl formation in the presence of SR $\mathrm{Ca}^{2+}$ ATPase and actin, whereas no effects were observed on incubation with monomeric vanadate. ${ }^{7,10,27}$ This reactivity of $V_{10}$ was attributed to the involvement of cysteines at the $\mathrm{V}_{10^{-}}$ binding site, as well as the participation of reduced vanadyl $\left(\mathrm{V}^{\mathrm{IV}}\right.$-containing) species in the enzymatic inhibition process. ${ }^{10}$ It is known that actin, in common with other proteins such as transferrin and albumin, contains a high affinity binding site for vanadyl. ${ }^{7}$ Decavanadate interactions with certain proteins can thus lead to vanadyl protein binding, although the participation of vanadyl in the process is yet to be clarified. ${ }^{10}$

Other mono- and polyoxometalates, such as niobates, tungstates and molybdates, have also been evaluated in the inhibition of SR calcium ATPase and were found to be less active as inhibitors. ${ }^{28}$ The decavanadate, $\mathrm{V}_{10}$, and decaniobate $\left(\mathrm{Nb}_{10}\right.$ $=\left[\mathrm{Nb}_{10} \mathrm{O}_{28}\right]^{6-}$ ) ions are isostructural and isovalent, but where vanadium is redox active and labile in solution, niobium is kinetically inert and redox stable, making $\mathrm{Nb}_{10}$ an excellent tool to explore the mode of inhibition that the $\mathrm{V}_{10}$ analogue undergoes with the proteins. ${ }^{27,28}$

The $\mathrm{Nb}_{10}$ and $\mathrm{V}_{10}$ compounds differ in their sizes, their ability to dissociate, their acid-base chemistry and their dissociation products. For example, there are no equivalents to the oligomeric metavanadates for niobium, which dissociates to the hexaniobate Lindqvist ion $\left(\mathrm{Nb}_{6}=\left[\mathrm{Nb}_{6} \mathrm{O}_{19}\right]^{8-}\right)$ and derivatives. In spite of these differences the decaniobate ion can be a useful tool to understand the mechanism and biological activities of the decavanadate ion because of the structural similarity and relatively inert behaviour. ${ }^{27,28}$

Raman spectroscopy has been shown to be a suitable tool for investigating vanadate speciation, including oligomerization and its dependence on concentration, ionic strength and $\mathrm{pH}^{29}$ as well as decavanadate interactions with different $\mathrm{Ca}^{2+}$ ATPase conformations. ${ }^{27}$ We presently use Raman spectroscopy to further characterize aqueous solutions of decavanadate and decaniobate in order to determine differences in the ensemble of oligomeric species present under experimental conditions, which may be important in biochemical studies where the two families of ions are compared..$^{27,28}$ The application of vibrational spectroscopy to niobate solutions is particularly important because, although the predominant $\mathrm{Nb}$ nucleus is NMR active $\left({ }^{93} \mathrm{Nb} ;=9 / 2\right)$, it yields broad lines in solution because of quadrupolar broadening. In contrast, vanadium NMR ${ }^{51} \mathrm{~V} ; I=7 / 2$ ) yields relatively narrow lines as it is less affected by quadrupolar broadening. Niobate speciation can only be practically monitored by NMR by enriching the compounds with ${ }^{17} \mathrm{O}$ and watching the ${ }^{17} \mathrm{O}$ NMR signal area change with time, but this is inherently limited ${ }^{30}$ and expensive.
In contrast with vanadate, there is less precedence for Raman spectroscopy on niobate solutions. Apart from a few examples of Raman spectra of the $\left[\mathrm{Nb}_{6} \mathrm{O}_{19}\right]^{8-}$ ion at static $\mathrm{pH}^{31,32}$ early $\mathrm{pH}$-dependent work was carried out prior to the isolation of $\mathrm{Nb}_{10}$, leading researchers then ${ }^{33}$ and $\operatorname{later}^{34}$ to assign the signals of this ion to a dodecameric species, which required later revision. In addition, a tetrameric niobate was reported by Spinner et al. ${ }^{33}$ but this putative oligomer has never been isolated. There is thus a need for spectroscopic Raman data of niobate species to correct the existing literature.

\section{Materials and methods}

All reagents were of biochemical analysis grade and were supplied by BDH, Merck, and Sigma. Anhydrous ammonium metavanadate was purchased from Riedel-de Haën. Tetramethylammonium decaniobate, $\left[\mathrm{N}\left(\mathrm{CH}_{3}\right)_{4}\right]_{6}\left[\mathrm{Nb}_{10} \mathrm{O}_{28}\right] \cdot 6 \mathrm{H}_{2} \mathrm{O}$, was synthesised according to published procedures. ${ }^{35}$ The synthesis of $\mathrm{K}_{7} \mathrm{H}\left[\mathrm{Nb}_{6} \mathrm{O}_{19}\right]$ was via adaptation of a standard method. ${ }^{36}$

\subsection{Preparation of solutions}

Decavanadate stock solution was prepared in MilliQ water (conductivity $<0.055 \mu \mathrm{S} \mathrm{cm}{ }^{-1}$ at $25^{\circ} \mathrm{C}$ ), by adjusting the $\mathrm{pH}$ of an ammonium metavanadate solution (50 mM, pH 6.7) to 4.0, according to literature methods, ${ }^{26,27}$ and the formation of the $\mathrm{V}_{10}$ ion was readily observed by the characteristic orange-yellow colour of the solution. ${ }^{4}$ Thus, we obtained a stock decavanadate concentration of $5 \mathrm{mM} \mathrm{V}_{10}$ (i.e. $50 \mathrm{mM}$ total vanadium, $\sim 50 \mathrm{mM} \mathrm{NH}_{4}^{+}$). A solution of $\mathrm{Nb}_{10}$ was prepared in water as a stock concentration of $5 \mathrm{mM}$ (i.e. $50 \mathrm{mM}$ of niobium) by dissolving the tetramethylammonium salt. $\mathrm{pH}$ meter calibration was performed before each measurement with three standards from Hanna (4.01, 7.01 and 10.01). The solutions were prepared in MilliQ water (conductivity $<0.055 \mu \mathrm{S} \mathrm{cm}^{-1}$ at $25{ }^{\circ} \mathrm{C}$ ). The $\mathrm{pH}$ was adjusted by the addition of $0.1 \mathrm{M}$ of $\mathrm{HCl}$ or $0.1 \mathrm{M}$ $\mathrm{NaOH}$.

\subsection{NMR spectroscopy}

${ }^{51} \mathrm{~V}$ NMR spectroscopy measurements of $\mathrm{V}_{10}$ and vanadate stock solutions were performed on a Bruker AM-400 $\mathrm{MHz}$ (9.4 T; $\left.{ }^{51} \mathrm{~V} 105.2 \mathrm{MHz}\right)$ spectrometer equipped with a $5 \mathrm{~mm}$ multinuclear inverse probe. The spectra were acquired at $22{ }^{\circ} \mathrm{C}$ using $0.5 \mathrm{~mL}$ of samples containing $10 \% \mathrm{D}_{2} \mathrm{O}$ using a calibrated $\pi / 2$ pulse. 12000-25000 scans were acquired with recycling delays of $10 \mathrm{~ms}$ and acquisition times of $86 \mathrm{~ms}$ at a spectral width of $45.454 \mathrm{kHz}$. The ${ }^{51} \mathrm{~V}$ NMR chemical shifts are reported relative to an external reference of $\mathrm{VOCl}_{3}$, as described in previous work. ${ }^{28}$

\subsection{High resolution Raman spectroscopy}

The Raman spectra were recorded at room temperature, in a triple monochromator HORIBA Jobin-Yvon T64000 Raman system (focal distance $0.64 \mathrm{~m}$, aperture $f / 7.5$ ), equipped with 
holographic gratings of 1800 grooves per mm. The premonochromator stage was used in the subtractive mode. The detection system was a liquid-nitrogen-cooled non-intensified 1024 $\times 256$ pixel (1") Charge Coupled Device (CCD) chip. A $90^{\circ}$ geometry between the incident radiation and the collecting system was employed. The entrance slit was set to $200 \mu \mathrm{m}$, while the slit between the premonochromator and the spectrograph was set to $3.5 \times 10^{4} \mu \mathrm{m}$. The $514.5 \mathrm{~nm}$ line of an $\mathrm{Ar}^{+}$ laser (Coherent, Innova model 305) was used as the excitation radiation, providing ca. $50 \mathrm{~mW}$ at the sample position. Samples were sealed in Kimax glass capillary tubes of $0.8 \mathrm{~mm}$ inner diameter. The system was calibrated against the crystalline silicon $521 \mathrm{~cm}^{-1}$ band. Under the above mentioned conditions, the error in wavenumbers was estimated to be less than $1 \mathrm{~cm}^{-1}$ and the resolution was better than 2 pixels of the CCD, i.e. $2 \mathrm{~cm}^{-1}$.

\subsection{Low resolution Raman spectroscopy}

Low resolution spectra were recorded on a Bayspec Agility Raman spectrometer equipped with a $785 \mathrm{~nm}$ laser working at $300 \mathrm{~mW} .10 \mathrm{mM} \mathrm{Nb}{ }_{10}$ samples were prepared by adding $25 \mathrm{mg}$ of solid $\mathrm{Nb}_{10}$ to the buffer solutions $(1.5 \mathrm{ml}, 0.1 \mathrm{M})$ with the $\mathrm{pH}$ already pre-adjusted using dropwise addition of $\left[\mathrm{N}\left(\mathrm{CH}_{3}\right)_{4}\right]$ $\mathrm{OH}(1.0 \mathrm{M})$ in order to avoid $\mathrm{pH}$ shock. The $\mathrm{pH}$ value was recorded after the $\mathrm{Nb}_{10}$ addition. The following buffers and pH were used: MES ( $\mathrm{pH}$ 6.13), PIPES ( $\mathrm{pH}$ 7.28), HEPES ( $\mathrm{pH}$ 8.18), CHES ( $\mathrm{pH} 9.05)$, CAPS ( $\mathrm{pH} 10.08$ and $\mathrm{pH} \sim 11.12$ ) and $\left[\mathrm{N}\left(\mathrm{CH}_{3}\right)_{4}\right] \mathrm{OH}(\mathrm{pH} \sim 12.80)$. The $\mathrm{pH}$ was measured with a Sigma-Aldrich micro $\mathrm{pH}$ combination electrode calibrated between pH 4.01 and 10.01. The alkaline error is likely to be very significant only for the $0.1 \mathrm{M}\left[\mathrm{N}\left(\mathrm{CH}_{3}\right)_{4}\right] \mathrm{OH}$ solution $(\mathrm{pH}$ 12.80). The solutions were pressed through 0.2 micrometer membrane filters which diminish, but do not eliminate, the Tyndall effect, as is typical. Spectra were collected after $c a$. four hours at $293 \mathrm{~K}$. The speciation diagram in Fig. 3 was constructed assuming that the signal intensity of $10 \mathrm{mM} \mathrm{Nb}_{10}$ was ca. 70 cps.

\subsection{Computational details}

All calculations were performed with Gaussian 09 rev B. ${ }^{37}$ All structures were optimised using the PBE0 (PBE1PBE) exchange correlation functional and the def2-tzvp basis set, using an ultrafine grid and implicit water solvation using the polarizable continuum model. ${ }^{38}$ Basis sets were obtained from the Basis Set Exchange. ${ }^{39}$ Raman calculations were carried out at the same level of theory as the optimisations.

\section{Results and discussion}

\subsection{NMR spectroscopy}

Decavanadate and $\mathrm{Nb}_{10}$ are isostructural and isoelectronic nanometre-sized polyoxometalate anions (Fig. 1). These relatively inflexible and structurally compact anions contain three types of metal sites: one site with four equivalent niobium (or vanadium) atoms above and below the major

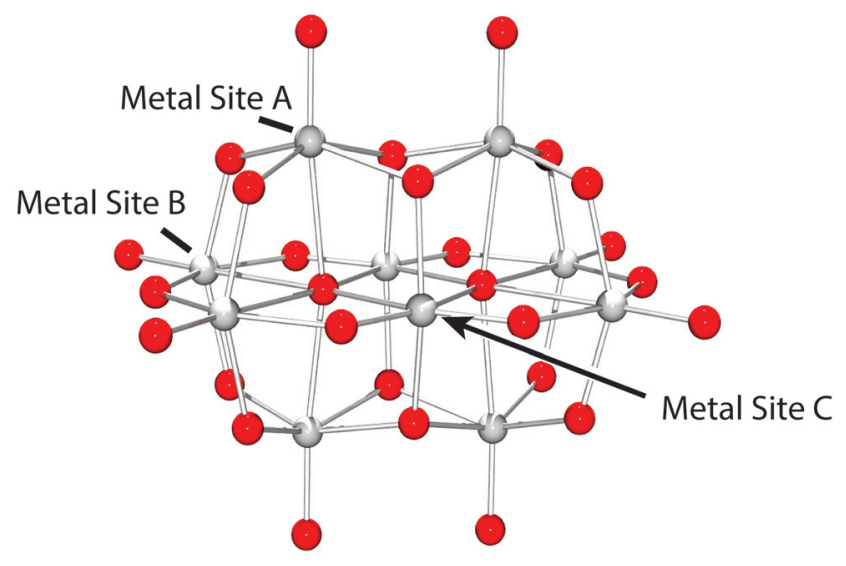

Fig. 1 Structure of the $\mathrm{V}_{10}$ and the $\mathrm{Nb}_{10}$ ions. The grey (light color) and red (dark color) spheres represent vanadium/niobium and oxygen atoms, respectively. The $\langle\mathrm{Nb}-\mathrm{O}\rangle$ bond lengths are $0.05-0.2 \AA$ longer than the corresponding $\langle\mathrm{V}-\mathrm{O}\rangle$ bond lengths, making $\mathrm{Nb}_{10}$ slightly larger than $\mathrm{V}_{10}$.

equatorial plane (metal site A), one site with four equivalents in that plane (metal site B), and one site with two equivalents in both the major and minor equatorial planes (metal site $\mathrm{C}$ ) (Fig. 1).

${ }^{51} \mathrm{~V}$-NMR spectroscopic studies demonstrated that, after acidification of the metavanadate solution from $\mathrm{pH} 6.7$ to $\mathrm{pH}$ 4.0 , we obtain a $\mathrm{V}_{10}$ solution containing decameric vanadate species (Fig. 2). The identity was confirmed by the presence of

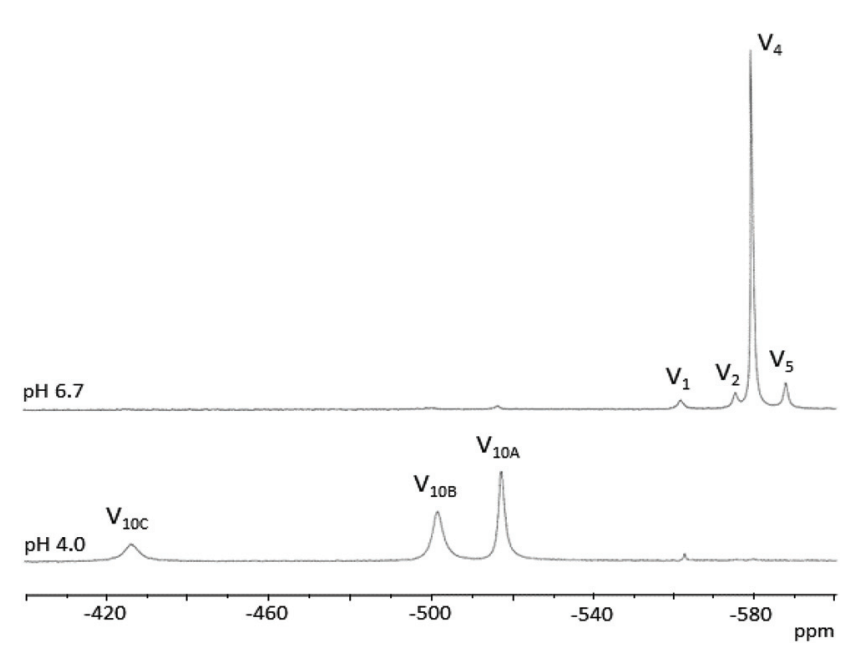

Fig. $2{ }^{51} \mathrm{~V}$ NMR (105.2 MHz, 9.4 T) spectra, at ambient temperature of $50 \mathrm{mM}$ (total vanadium) concentration of decavanadate $(\mathrm{pH} 4.0)(\mathrm{A})$ and metavanadate solutions ( $\mathrm{pH}$ 6.7) (B). All spectra were acquired in the presence of $10 \% D_{2} O . V_{10 A}, V_{10 B}$ and $V_{10 C}$ represent signals of vanadium sites in $\mathrm{V}_{10}$. The ${ }^{51} \mathrm{~V}$ NMR $\mathrm{V}_{1}$ signals correspond to the orthovanadate species namely, monomeric vanadate $\left(\mathrm{VO}_{4}{ }^{3-}, \mathrm{HVO}_{4}{ }^{2-}\right.$ and $\left.\mathrm{H}_{2} \mathrm{VO}_{4}{ }^{-}\right)$, whereas the metavanadate species includes dimeric $\mathrm{V}_{2}\left(\mathrm{HV}_{2} \mathrm{O}_{7}{ }^{3-}\right.$ and $\mathrm{H}_{2} \mathrm{~V}_{2} \mathrm{O}_{7}{ }^{2-}$ ), regardless of the state of protonation, $\mathrm{V}_{4}$ and $\mathrm{V}_{5}$, that corresponds to cyclic tetrameric $\left(\left[\mathrm{V}_{4} \mathrm{O}_{12}\right]^{4-}\right)$ and pentameric vanadate $\left(\left[\mathrm{V}_{5} \mathrm{O}_{15}\right]^{5-}\right)$, respectively. 
three NMR signals at $-517,-501$ and $-426 \mathrm{ppm}$, respectively, corresponding to the three metal sites: $\mathrm{V}_{10 \mathrm{~A}}, \mathrm{~V}_{10 \mathrm{~B}}$ and $\mathrm{V}_{10 \mathrm{C}}$ (Fig. 2), in the expected intensity ratios. As can be observed by ${ }^{51} \mathrm{~V} \mathrm{NMR}$, the solutions of $5 \mathrm{mM} \mathrm{V} \mathrm{V}_{10}(50 \mathrm{mM}$ total vanadium, $\mathrm{pH}$ 4.0) contain mainly $\mathrm{V}_{10}$ species (Fig. 2). Conversely, in the NMR spectrum of a $50 \mathrm{mM}$ metavanadate solution ( $\mathrm{pH}$ 6.7), signals attributed to mono- $\left(\mathrm{V}_{1}\right)$, di- $\left(\mathrm{V}_{2}\right)$, tetra- $\left(\mathrm{V}_{4}\right)$ and pentameric $\left(\mathrm{V}_{5}\right)$ species of vanadate can be observed, respectively, at $-561 \mathrm{ppm},-575 \mathrm{ppm},-579 \mathrm{ppm}$ and $-587 \mathrm{ppm}$ (Fig. 2), as previously described. ${ }^{4}$ As expected, we observe that acidification of a colorless metavanadate solution turns the solution yellow/orange due to $\mathrm{pH}$ shock and metastable formation of the $\mathrm{V}_{10}$ ion, which dissociates slowly even at a $\mathrm{pH}$ where it is not ultimately stable. By 'pH shock' we mean that metastable species form upon addition of a drop of a base or acid, and these species are kinetically persistent. Upon acidification of $50 \mathrm{mM}$ and higher vanadate concentrations it is possible to observe the solution becoming dark for a while at $\mathrm{pH}$. This indicates that the species that forms are not thermodynamically stable at $\mathrm{pH}$. Most likely it is due to $\mathrm{pH}$ shock. To the best of our knowledge, only $\mathrm{VO}^{2+}$ and $\mathrm{H}_{x} \mathrm{~V}_{10} \mathrm{O}_{28}{ }^{(6-x)-}$ are coloured, so one of these species would be suggested to be formed. The latter would be formed at the $\mathrm{pH}$ near the $\mathrm{pH}$ of the acid added to the vanadate solutions and that would imply the reduction of vanadate species whereas the former due to vanadate oligomerization. The observation of the formation of these species would not be feasible or possible by NMR and/or Raman spectroscopy. However, kinetic studies using UV-Vis spectroscopy would be suitable to follow the formation and disappearance of these species.

The speciation diagram for aqueous solutions of vanadate shows that the $\mathrm{V}_{10}$ ion dominates between 2.5 and 5.8, to the point where it represents all of the total vanadate species at pH 3.0-5.0 (Fig. 3a). Similarly, the $\mathrm{Nb}_{10}$ ion is the dominant signal at $5.5<\mathrm{pH}<9.90$ and is detectable up to $\mathrm{pH} \sim 10.8$, whereas $\mathrm{V}_{10}$ slowly dissociates at most $\mathrm{pH}$ values and $\mathrm{Nb}_{10}$ converts quantitatively to the hexaniobate product at $\mathrm{pH} \sim 11$ (Fig. 3b). To date, there is no comprehensive speciation model for niobate aqueous solutions, as opposed to vanadate. However, ${ }^{17} \mathrm{O}$ NMR experiments have shown that the $\mathrm{Nb}_{10}$ species is stable for weeks between $\mathrm{pH} 5.5$ and 7.5. Under higher $\mathrm{pH}$ conditions, the dissociation is detectable as a slow loss of signal from an internal oxygen in ${ }^{17} \mathrm{O}$-enriched compounds. ${ }^{30}$ The authors found the dissociation products to include the $\mathrm{Nb}_{6}$ Lindqvist ion. ${ }^{40}$ This dissociation is suspected to be reversible, based in part on isotope-transfer between the $\mathrm{Nb}_{10}$ and $\mathrm{Nb}_{6}$ although the thermodynamics of the equilibrium remains unexplored. ${ }^{40}$ Direct acidification of $\mathrm{Nb}_{10}$ in aqueous solution leads to the precipitation of a white powder referred to as 'niobic acid' in the literature. A dimer of the decaniobate ion, $\left[\mathrm{Nb}_{20} \mathrm{O}_{54}\right]^{8-}$, can be formed in dichloromethane at low $\mathrm{pH} \cdot{ }^{30}$ Little is known about the behaviour at very high $\mathrm{pH}(>14)$ but as salts of $\left[\mathrm{NbO}_{4}\right]^{3-}$ are only known as insoluble solids, and $\mathrm{K}_{7} \mathrm{H}\left[\mathrm{Nb}_{6} \mathrm{O}_{19}\right]$ is synthesised in molten $\mathrm{KOH},{ }^{36}$ it is unlikely that there is any polyoxoniobate chemistry beyond the $\mathrm{Nb}_{6}$ ion in the alkaline direction.
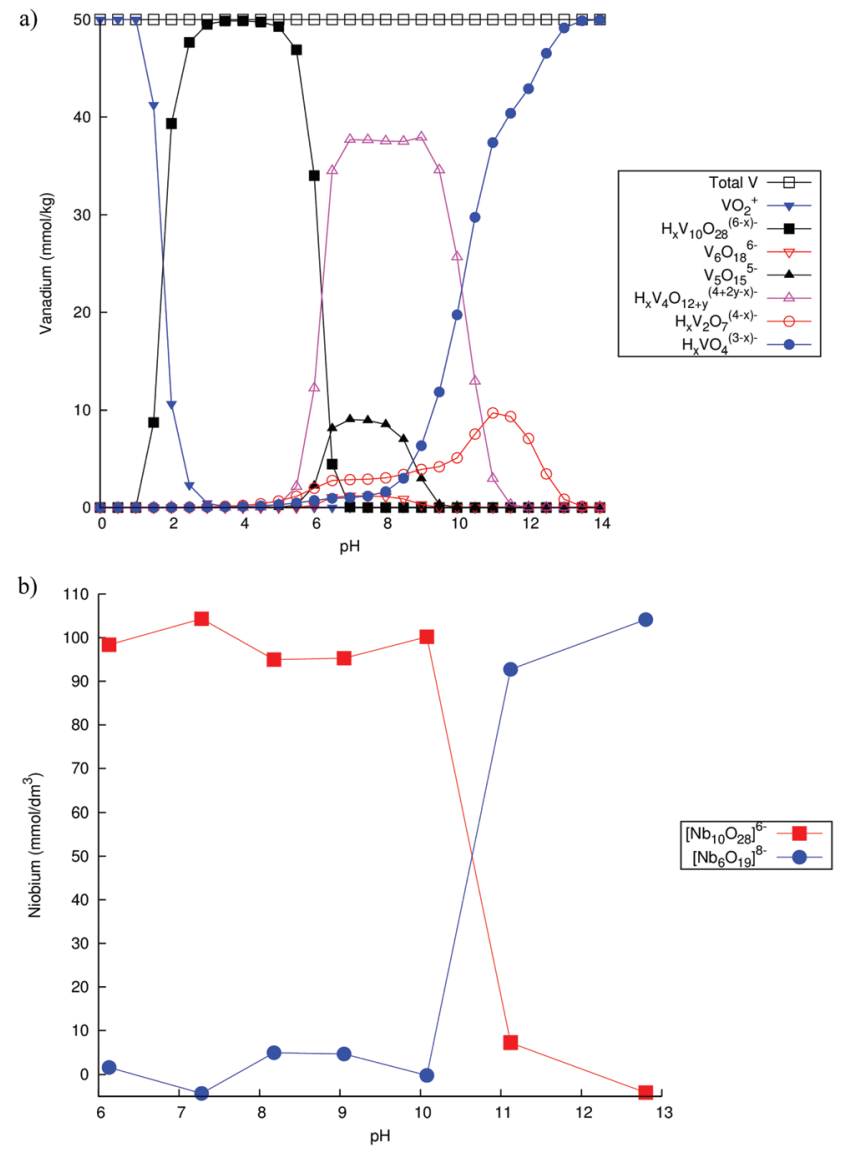

Fig. 3 (A) Speciation diagram based on ${ }^{51} \mathrm{~V}-\mathrm{NMR}$, for an aqueous 50 millimolal $\left(50 \mathrm{mmol} \mathrm{\textrm {kg } ^ { - 1 }}\right.$ ) solution of vanadium(v) at $\mathrm{pH} 0-14$, showing the atomic concentration of vanadium i.e. the molecular concentration of each species is multiplied by the number of vanadium atoms incorporated into it. The speciation at each $\mathrm{pH}$ was computed using Visual MINTEQ v3.0 [http://vminteq.lwr.kth.se/] in the presence of $1.0 \mathrm{M} \mathrm{NaCl}$ with a fixed $1.0 \mathrm{M}$ ionic strength using the SIT model. ${ }^{44}$ (B) Speciation diagram of niobates at $293 \mathrm{~K}$ at ca. $0.1 \mathrm{M}$ ionic strength based on the current Raman spectrometric work. See the text for details as well as the ESI. $\dagger$

\subsection{Raman spectroscopy}

We presently examine the stability of $\mathrm{V}_{10}$ species by Raman spectroscopy. A pH 4-12 range was chosen because it covers the biologically interesting range. On the other hand, the niobates condense by proton-induced charge neutralization under lower $\mathrm{pH}$ conditions whereas decavanadate persists under slightly lower $\mathrm{pH}$ conditions. Nevertheless, our focus was on the rich speciation chemistry at neutral $\mathrm{pH}$ and above. Fig. 4 depicts the Raman spectra of a $5 \mathrm{mM} \mathrm{V}_{10}$ solution in the $900-1100 \mathrm{~cm}^{-1}$ region, for $\mathrm{pH}$ values ranging from 7.47 to 6.45. In this $\mathrm{pH}$ range, the signals are assignable to the vO symmetric stretching vibration of different oligomeric species. In particular, the band at $995 \mathrm{~cm}^{-1}$ is due to the $V_{10}$ species. This prevalence of $V_{10}$ is in contrast with what is expected taking in consideration the speciation diagram for thermodynamically equilibrated solutions in this $\mathrm{pH}$ range, which predicts that the solution should not contain any appreciable 


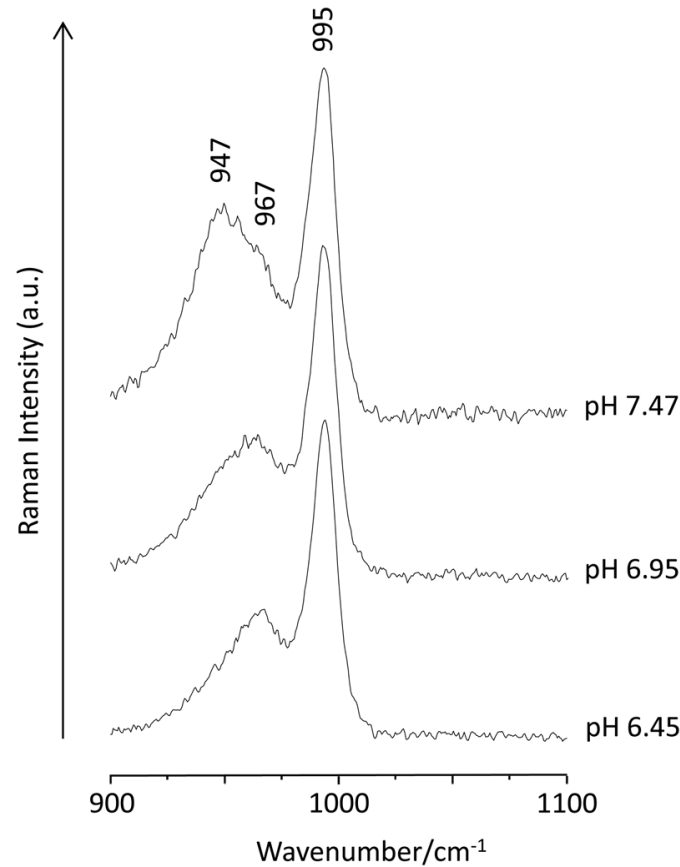

Fig. 4 Raman spectra of decavanadate solutions $(50 \mathrm{mM}$ total vanadium) from $\mathrm{pH} 6.45$ to 7.47 .

amount of $\mathrm{V}_{10}$, but mainly $\mathrm{V}_{4}$, with some $\mathrm{V}_{5}, \mathrm{~V}_{2}$ and $\mathrm{V}_{1}$. In fact, the spectra undergo a sequence of changes with $\mathrm{pH}$ : at $\mathrm{pH}$ 6.95 an additional band at $947 \mathrm{~cm}^{-1}$ begins to emerge and becomes completely distinguishable at pH 7.47 (Fig. 4). This signal clearly corresponds to another species, probably a tetrameric vanadate resulting from some $\mathrm{V}_{10}$ decomposition. This disparity is due to the solution being $\mathrm{pH}$ shocked and still under kinetic control.

The ${ }^{51} \mathrm{~V}$ NMR studies showed that on acidification of vanadate solutions ( $\mathrm{pH}$ 6.6), $\mathrm{V}_{10}$ appears together with the $\mathrm{V}_{1}, \mathrm{~V}_{2}$ and $\mathrm{V}_{4}$ which were already present in the vanadate solution at $\mathrm{pH}$ 6.8. ${ }^{4}$ Raman bands ascribed to $\mathrm{V}_{10}$ are also observed at 315 and $593 \mathrm{~cm}^{-1}$, in addition to the ones at 967 and around $995 \mathrm{~cm}^{-1}$ (Fig. 5). These $\mathrm{V}_{10}$ former bands are clearly visible in the Raman spectrum from 4.0 to $\mathrm{pH} 8.59$ (Fig. 5). Conversely, at $\mathrm{pH} 8.97 \mathrm{~V}_{10}$ is no longer detectable, whereas the band at $947 \mathrm{~cm}^{-1}$ that began to emerge at $\mathrm{pH} 6.95$ increasingly dominates the spectrum for higher $\mathrm{pH}$ values (Fig. 5). This signal was assigned in a previous study, ${ }^{26}$ to the symmetric stretching vibration mode from $V_{4}$ and $V_{5}$ species, which agrees with the predicted speciation diagram in Fig. 1. At pH 9.52 a band, allocated to $\mathrm{V}_{2}$ and $\mathrm{HV}_{1}$ species, arises at $875 \mathrm{~cm}^{-1}$. The band at $820 \mathrm{~cm}^{-1}$ assigned to the unprotonated $\mathrm{V}_{1}$ species is only observed at a $\mathrm{pH}$ value close to $12 .{ }^{29}$ Furthermore, after two weeks of incubation at $40{ }^{\circ} \mathrm{C}$, similar spectra were obtained (not shown) for all the solutions described in Fig. 5.

In the Raman spectrum of decaniobate the bands at 936 and $270 \mathrm{~cm}^{-1}$ arise from the $\mathrm{Nb}_{10}$ ion (Fig. 6), with the band at $953 \mathrm{~cm}^{-1}$ ascribed to $\left[\mathrm{N}\left(\mathrm{CH}_{3}\right)_{4}\right]^{+}$. The $936 \mathrm{~cm}^{-1}$ signal, assigned to the $\mathrm{NbO}$ symmetric stretching vibration, appears

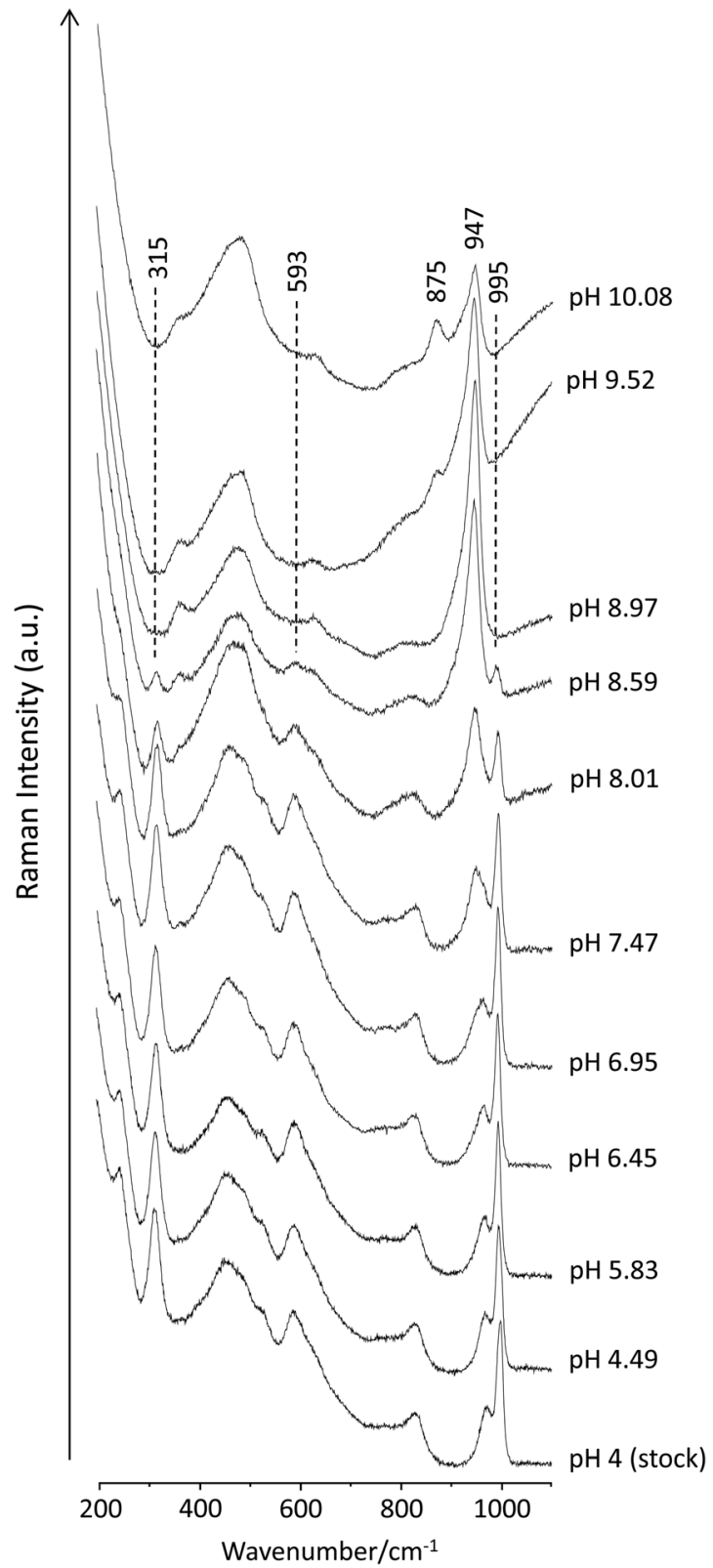

Fig. 5 Raman spectra (200 to $1100 \mathrm{~cm}^{-1}$ ) of decavanadate solutions ( $50 \mathrm{mM}$ total vanadium) from $\mathrm{pH} 4.00$ to 10.08 . The band between 400 and $500 \mathrm{~cm}^{-1}$ is due to the glass.

at a lower wavenumber than the corresponding one observed for the decavanadate, as expected assuming a similar force constant since niobium is a heavier element than vanadium. These bands are clearly observed up to pH 10.80 (Fig. 6), indicating the presence of $\mathrm{Nb}_{10}$ in the solution. No changes were observed on the spectra of the above solutions after two weeks of incubation at $40{ }^{\circ} \mathrm{C}$, pointing out that the $\mathrm{Nb}_{10}$ solutions were stable even at higher alkaline pH values (Fig. 7).

The literature evidence for dissociation of the $\mathrm{Nb}_{10}$ at $\mathrm{pH}>$ 7.6 is from clear ${ }^{17} \mathrm{O}-\mathrm{NMR}$ signal loss from oxygens in the center of the molecule. ${ }^{40}$ The ${ }^{17} \mathrm{O}$-NMR signal loss is quite slow and the authors suspected that there may be an equili- 


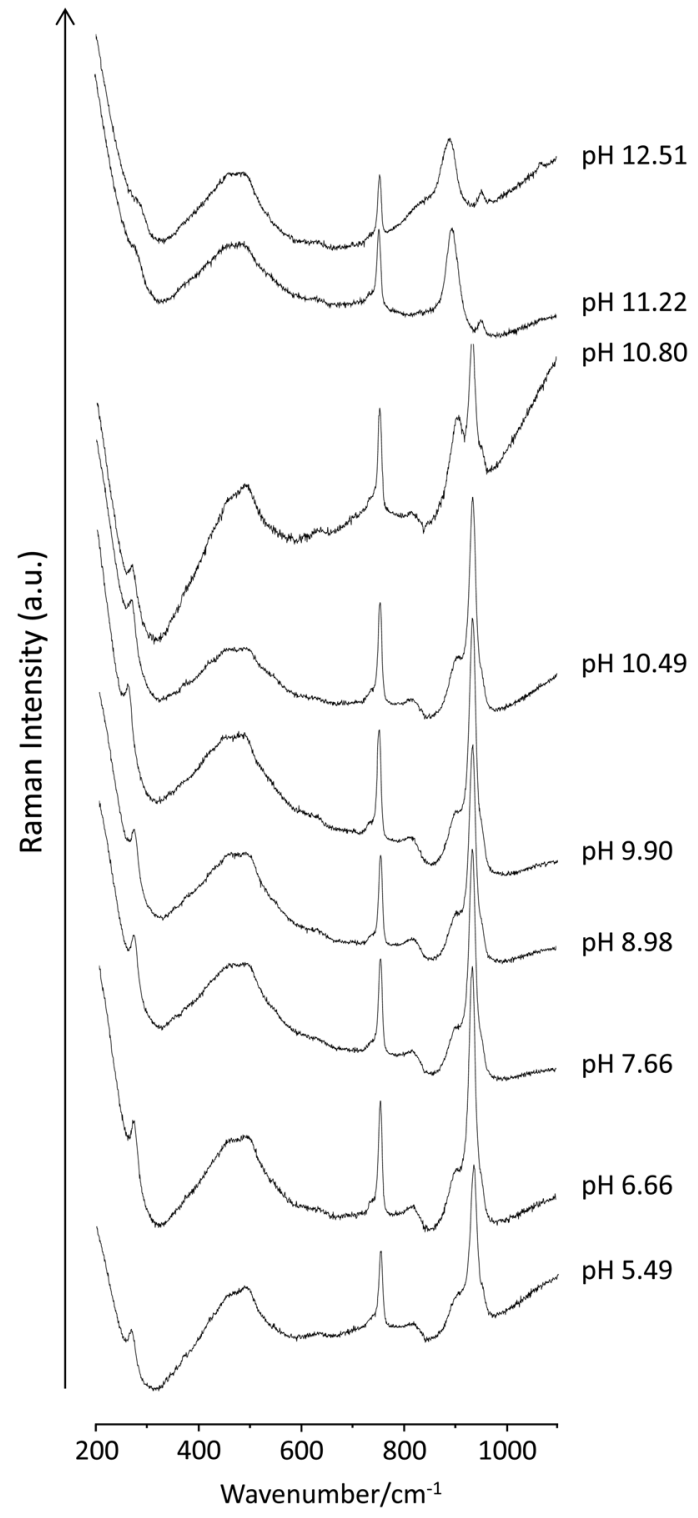

Fig. 6 Raman spectra (200 to $1100 \mathrm{~cm}^{-1}$ ) of decaniobate solutions (50 mM total niobium) from $\mathrm{pH} 5.49$ to 12.51 .

brium between the $\mathrm{Nb}_{10}$ and the $\mathrm{Nb}_{6}$ dissociation product. The Raman spectra are consistent with $\mathrm{Nb}_{10}$ being present in solution up to $\mathrm{pH} 10.80$ [Fig. 3b]. Thus, at $\mathrm{pH} 10.49$, a slight separation of bands is observed, and at $\mathrm{pH} 10.80$ the formation of a band at $889 \mathrm{~cm}^{-1}$ is attributed to the presence of $\mathrm{Nb}_{6}$ (Fig. 6). Also there is no difference in the Raman spectra at $\mathrm{pH} 11.22$ and 12.51 (Fig. 6). Furthermore, $\mathrm{Nb}_{10}$ species are kinetically stable and present in solution up to $\mathrm{pH} 9.90$ for at least two weeks at $40{ }^{\circ} \mathrm{C}$, even for the higher $\mathrm{pH}$ values analysed (Fig. S1 $\dagger$ ). In fact, there is no description in the literature of species in solution smaller than $\mathrm{Nb}_{6}$, suggesting that this species is stable at very high $\mathrm{pH}$, as we discussed above.

In an attempt to obtain a more quantitative view of the solution compositions, we collected additional data on a lowpower, low-resolution instrument on samples prepared using
$0.1 \mathrm{M}$ biological buffers to avoid the influence of $\mathrm{pH}$ shock that might result from the addition of an acid or base to solutions of the niobates. As can be seen in Fig. 7, the results show that it is possible to collect quantitative solution composition data for niobates even in the presence of stabilising buffers.

The results broadly agree with previous data by Villa $e t$ al. based on the ${ }^{17} \mathrm{O}$ NMR spectra of ${ }^{17} \mathrm{O}$-enriched $\mathrm{Nb}_{10}$ acquired at $35{ }^{\circ} \mathrm{C}$ which showed that $\mathrm{Nb}_{10}$, at concentrations of $0.6 \mathrm{M}$ (total $\mathrm{Nb}$ ), slowly dissociates to $\mathrm{Nb}_{6}$ at and above $\mathrm{pH} 7.5$, with the dissociation occurring increasingly rapidly with increasing $\mathrm{pH}$ and can be affected by solution composition. ${ }^{30}$ The reaction has been observed to be at least partially reversible by the dissolution of $\mathrm{Nb}_{6}$ in a borate buffer and subsequent analysis by ESI-MS after 24 hours at room temperature, a result that was confirmed by Klemperer $e t$ al., who noted that the formation of $\mathrm{Nb}_{10}$ from $\mathrm{Nb}_{6}$ was favoured by increasing temperature. ${ }^{41}$

In either case, Raman spectra may here present a unique opportunity for the thermodynamic resolution of the equilibrium between $\mathrm{Nb}_{6}$ and $\mathrm{Nb}_{10}$, which would constitute the first example of quantitative speciation data for any polyoxoniobate species. It also does not escape our attention that a similar approach could be used to detail the relationship between $\left[\mathrm{Ta}_{6} \mathrm{O}_{19}\right]^{8-}$ and $\left[\mathrm{Ta}_{10} \mathrm{O}_{28}\right]^{6-}$, the latter being isolated only recently. ${ }^{42}$

\subsection{Comparison between computed and observed spectra}

The electronic-structure calculations predict features of the Raman spectra well, with a systematic over-estimation of the reciprocal wavenumber (Fig. 8). Experimentally, $\mathrm{V}_{10}$ exhibits a strong band at $995 \mathrm{~cm}^{-1}$, which is predicted computationally (Fig. 8d) to manifest at $1059 \mathrm{~cm}^{-1}$, together with bands between 614 and $627 \mathrm{~cm}^{-1}$ and at $334 \mathrm{~cm}^{-1}$ which are experimentally found at 593 and $315 \mathrm{~cm}^{-1}$, respectively. This tendency to overestimate the wavenumber of the signal is persistent and wellknown ${ }^{43}$ with the signal from $\mathrm{V}_{4}$ showing up at $947 \mathrm{~cm}^{-1}$, but being predicted to occur at $1002 \mathrm{~cm}^{-1}$ (Fig. 8c). The most important point, however, is that the calculations capture the general trend of the signals shifting to a lower frequency with decreasing chain length, as well as the decavanadate species having two pronounced signals around $1000 \mathrm{~cm}^{-1}$ (Fig. 8d).

The qualitative and quantitative agreement is much better for the niobate species, with a predicted signal maximum at $957 \mathrm{~cm}^{-1}$ (Fig. 8f) for $\mathrm{Nb}_{10}$ which was observed at $936 \mathrm{~cm}^{-1}$. However, as the main signal for the $\mathrm{Nb}_{6}$ occurs at $889 \mathrm{~cm}^{-1}$ but is expected at $858 \mathrm{~cm}^{-1}$, the good numerical agreement for $\mathrm{Nb}_{10}$ may be entirely fortuitous, which is unsurprising as the computations do not accurately account for hydrogen bonding and other factors that are known to influence the spectra (Fig. 8e and $\mathrm{f}$ ).

The $\left[\mathrm{N}\left(\mathrm{CH}_{3}\right)_{4}\right]^{+}$signals are expected at 817 and $1020 \mathrm{~cm}^{-1}$, but exhibit at 755 and $953 \mathrm{~cm}^{-1}$. The shapes and number of predicted signals agree well with experiment, lending some confidence in assignments for the observed signals. The main signal from the $\mathrm{Nb}_{10}$ at $957 \mathrm{~cm}^{-1}$ (computed shift) is due to a symmetric concerted stretch of the terminal oxygen sites away from the molecular centre, as is the main signal from the $\mathrm{Nb}_{6}$ ion at $858 \mathrm{~cm}^{-1}$. The $\mathrm{Nb}_{6}$ signals between 520 and $530 \mathrm{~cm}^{-1}$ are 


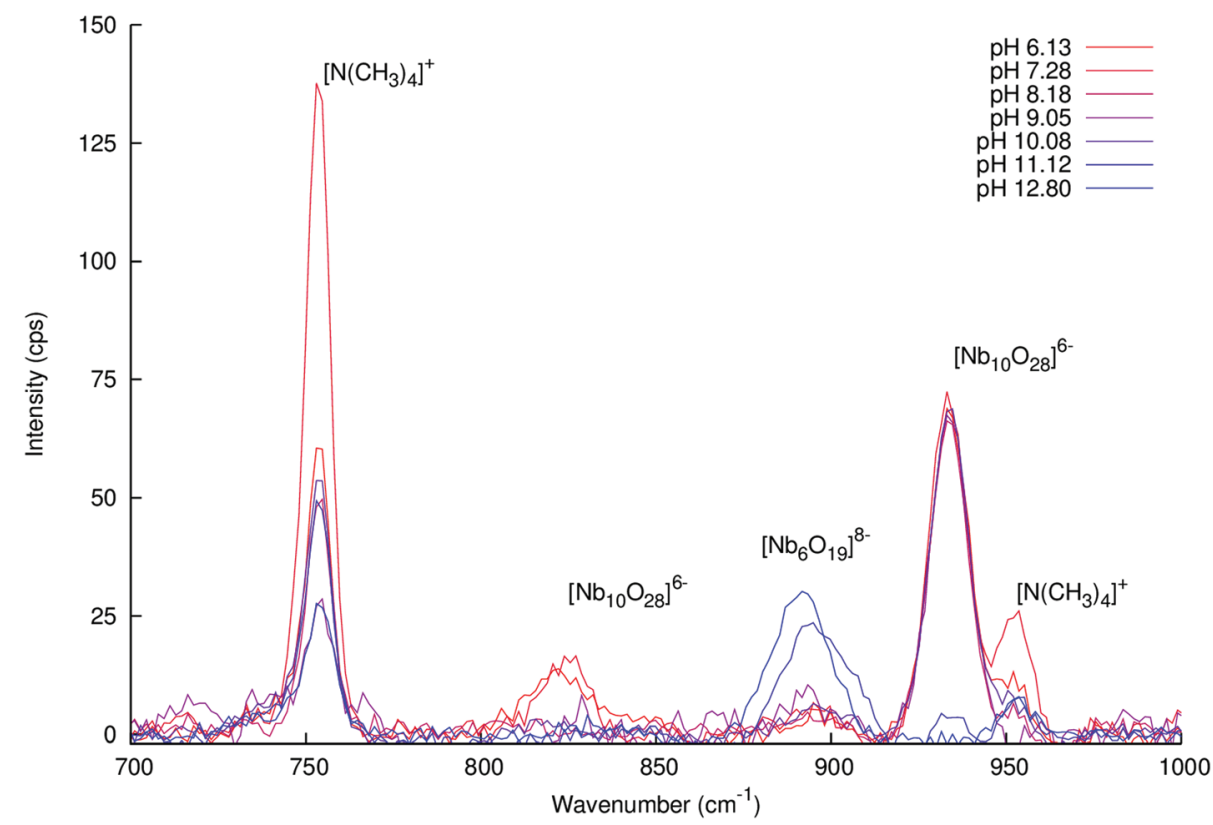

Fig. 7 Raman spectra of buffered solutions of $\mathrm{Nb}_{10}$ as a function of $\mathrm{pH}$. Note that the $\left[\mathrm{N}\left(\mathrm{CH}_{3}\right)_{4}\right]^{+}$concentration varies between solutions as $\left[\mathrm{N}\left(\mathrm{CH}_{3}\right)_{4}\right] \mathrm{OH}$ was used to adjust the $\mathrm{pH}$ of the buffers.
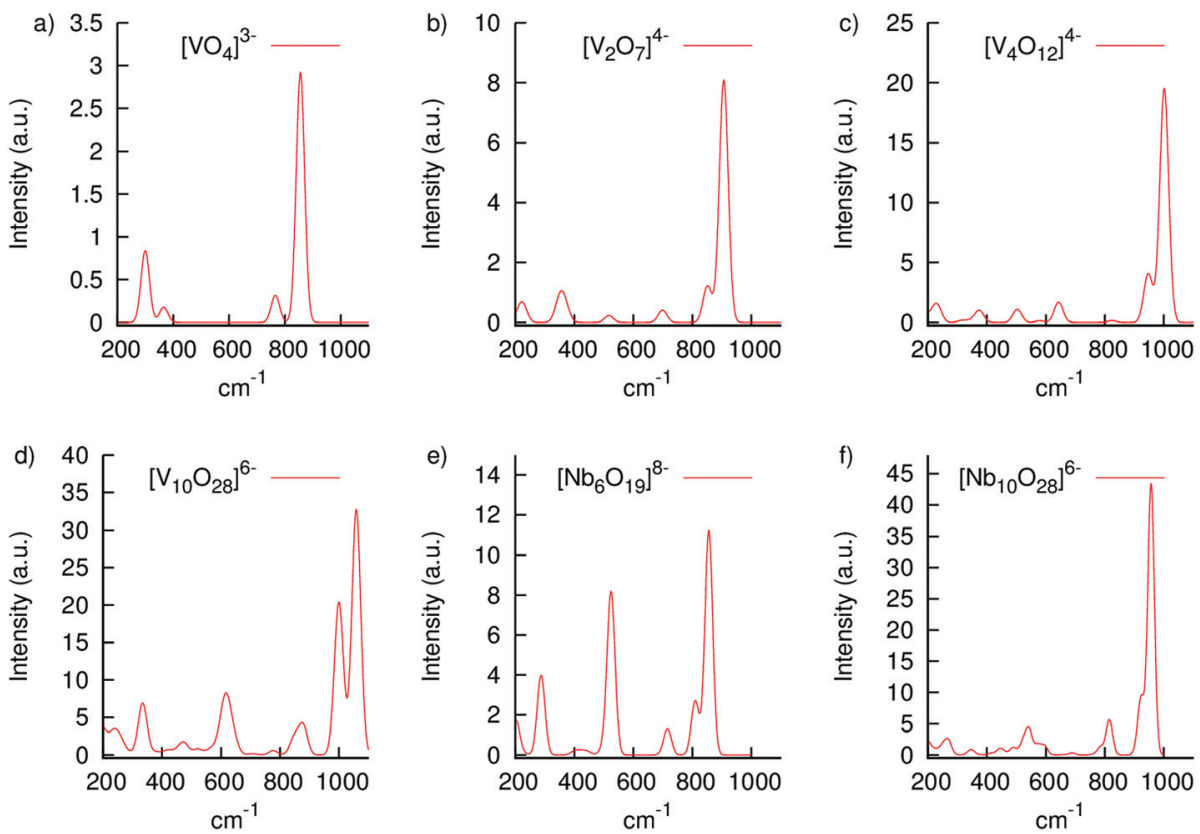

Fig. 8 Computed Raman spectra for select vanadate and niobate species. See the $\mathrm{ESI} \dagger$ for numerical data.

due to movements of the central oxygen along an axis, and to the sets of $\mu_{2}$-oxygens moving towards the molecular centre.

\section{Conclusions}

Raman spectra indicate that the $\mathrm{V}_{10}$ ion dominates in solution up to $\mathrm{pH} 6.45$ and that this species remains detectable in solu- tion until $\mathrm{pH} \sim 8.6$. On the other hand, the $\mathrm{Nb}_{10}$ ion is the dominant signal at $5.5<\mathrm{pH}<9.90$ and is detectable up to $\mathrm{pH}$ $\sim$ 10.8. Whereas $\mathrm{V}_{10}$ slowly dissociates at most $\mathrm{pH}$ values $\mathrm{Nb}_{10}$ converts quantitatively to the hexaniobate product at $\mathrm{pH} \sim 11$ (Fig. 9). Nevertheless, Raman spectra point out that both $\mathrm{V}_{10}$ and $\mathrm{Nb}_{10}$ solutions are stable in solution for at least two weeks and moderate heat, in the sense that they do not precipitate a solid and that $\mathrm{V}_{10}$ and $\mathrm{Nb}_{10}$ are still detectable over a wide $\mathrm{pH}$ 


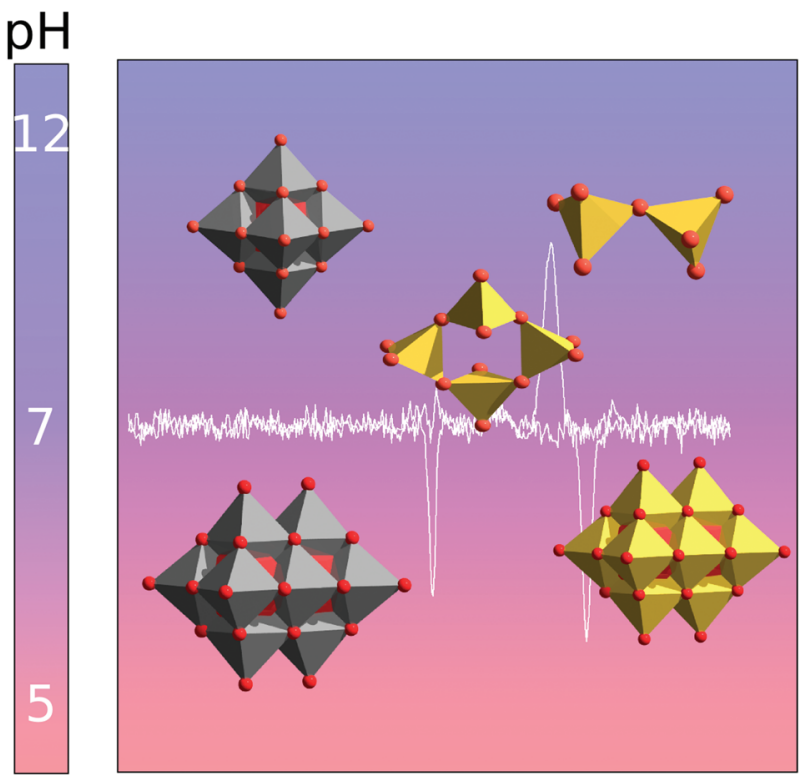

Fig. $9 \mathrm{~V}_{10}$ dissociates at most $\mathrm{pH}$ values into smaller tetrahedral vanadate oligomers such as $V_{4}$ and $V_{2}$, whereas $N_{10}$ dissociates into $\mathrm{Nb}_{6}$ under mildly or highly alkaline conditions.

range. Thus, Raman spectroscopy may be a potentially useful tool to characterize $\mathrm{Nb}_{10}$ and $\mathrm{V}_{10}$ species and their equilibrium with lower oligomers, which is extraordinarily difficult for niobate species because NMR is very difficult in the system. The vibrational properties, in contrast, can be established using electronic-structure methods a priori and used to assign the signals from putative minor aqueous species. These findings have important consequences for understanding the differences between decavanadate and decaniobate solution chemistry as well as its biological activities and pharmacological applications whenever a particular vanadate or niobate oligomer maybe desired and higher $\mathrm{pH}$ values are used.

\section{Abbreviations}

$\begin{array}{ll}\text { BMOV } & \text { Bis(maltolato)oxovanadium(Iv) } \\ \text { CAPS } & N \text {-Cyclohexyl-3-aminopropanesulfonic acid } \\ \text { CHES } & \text { N-Cyclohexyl-2-aminoethanesulfonic acid } \\ \text { HEPES } & \text { 4-(2-Hydroxyethyl)-1-piperazineethanesulfo- } \\ & \text { nic acid } \\ & \text { 2-(N-Morpholino)ethanesulfonic acid } \\ \text { MES } & \text { Piperazine- } N \text {, } N \text {-bis }(2 \text {-ethanesulfonic acid) } \\ \text { PIPES } & \text { Decaniobate ion }\left[\mathrm{Nb}_{10} \mathrm{O}_{28}\right]^{6-} \\ \mathrm{Nb}_{10} & \text { Hexaniobate Lindqvist ion, }\left[\mathrm{Nb}_{6} \mathrm{O}_{19}\right]^{8-} \\ \mathrm{Nb}_{6} & \text { Sarcoplasmic reticulum } \\ \mathrm{SR} & \text { Calcium pump from sarcoplasmic reticulum } \\ \mathrm{SR} \mathrm{Ca}^{2+} \text {-ATPase } & \text { Vanadium-51 NMR } \\ { }^{51} \mathrm{~V}_{-\mathrm{NMR}} & \text { Monomeric vanadate, }\left[\mathrm{VO}_{4}\right]^{3-} \\ \mathrm{V}_{1} & \text { Dimeric vanadate, }\left[\mathrm{V}_{2} \mathrm{O}_{7}\right]^{4-} \\ \mathrm{V}_{2} & \text { Tetrameric vanadate, }\left[\mathrm{V}_{4} \mathrm{O}_{12}\right]^{4-} \text { and }\left[\mathrm{V}_{4} \mathrm{O}_{13}\right]^{6-} \\ \mathrm{V}_{4} & \text { Pentameric vanadate, }\left[\mathrm{V}_{5} \mathrm{O}_{15}\right]^{5-} \\ \mathrm{V}_{5} & \text { Decavanadate ion, }\left[\mathrm{V}_{10} \mathrm{O}_{28}\right]^{6-} \\ \mathrm{V}_{10} & \end{array}$

\section{Acknowledgements}

MA, LAEBC and MPMM thanks the National Funds through FCT - Foundation for Science and Technology (UID/Multi/ 04326/2013 and UID/Multi/00070/2013). CAO is grateful for a QEII fellowship and Discovery Project grant (DP110105530) from the Australian Research Council. Some materials were provided by Prof. William Casey of U. C. Davis who prepared them with support from an NSF CCI grant through the Center for Sustainable Materials Chemistry, number CHE-1102637.

\section{References}

1 J. T. Rhule, C. L. Hill and D. A. Judd, Chem. Rev., 1998, 98, 327-357.

2 T. Yamase, J. Mater. Chem., 2005, 15, 4773-4782.

3 M. Aureliano, Oxid. Med. Cell. Longevity, 2016, 2016, 6103457, 8 pages.

4 M. Aureliano and D. C. Crans, J. Inorg. Biochem., 2009, 103, 536-546.

5 M. Aureliano, Dalton Trans., 2009, 9093-9100.

6 M. Aureliano, World J. Biol. Chem., 2011, 2, 215-238.

7 S. Ramos, J. J. G. Moura and M. Aureliano, Metallomics, 2012, 4, 16-22.

8 M. Aureliano, G. Fraqueza and C. A. Ohlin, Dalton Trans., 2013, 42, 11770-11777.

9 M. Aureliano, Inorg. Chim. Acta, 2014, 420, 4-7.

10 M. Aureliano and C. A. Ohlin, J. Inorg. Biochem., 2014, 137, 123-130.

11 N. Samart, J. Saeger, K. J. Haller, M. Aureliano and D. C. Crans, J. Mol. Eng. Mater., 2014, 2, 1440007.

12 L. Yan-Tuan, Z. Chun-Yuan, W. Zhi-Yong, M. Jiang and C.-W. Yan, Transition Met. Chem., 2010, 35, 597-603.

13 F. Zhai, X. Wang, D. Li, H. Zhang, R. Li and L. Song, Biomed. Pharmacother., 2009, 63, 51-55.

14 X. Niu, R. Xiao, N. Wang, Z. Wang, Y. Zhang, Q. Xia and X. Yang, Curr. Top. Med. Chem., 2016, 16, 811-822.

15 V. Dimitrova, K. Zhetcheva and L. P. Pavlova, J. Chem., 2011, 35, 215-223.

16 R. Raza, A. Matin, S. Sarwar, M. Barsukova-Stuckart, M. Ibrahim, U. Kortz and J. Iqbal, Dalton Trans., 2012, 41, 14329-14336.

17 A. Zorzano, M. Palacin, L. Marti and S. Garcia-Vicente, J. Inorg. Biochem., 2009, 103, 559-566.

18 M. J. Pereira, E. Carvalho, J. W. Eriksson, D. C. Crans and M. Aureliano, J. Inorg. Biochem., 2009, 103, 1687-1692.

19 G. Borges, P. Mendonça, N. Joaquim, M. Aureliano and J. M. Coucelo, Arch. Environ. Contam. Toxicol., 2003, 45, 415-422.

20 X. Chen, S. Yan, H. Wang, Z. Hu, X. Wang and M. Huo, Carbohydr. Polym., 2015, 117, 673-680.

21 L. Mohapatra and K. M. Parida, Phys. Chem. Chem. Phys., 2014, 16, 16985-16996.

22 A. Bijelic and A. Rompel, Coord. Chem. Rev., 2015, 299, 22-38. 
23 L. Pettersson, I. Andersson and A. Gorzsás, Coord. Chem. Rev., 2003, 237(1-2), 77-87.

24 A. Gorzsás, I. Andersson and L. Pettersson, J. Inorg. Biochem., 2009, 103, 517-526.

25 S. Ramos, M. Manuel, T. Tiago, R. O. Duarte, J. Martins, C. Gutiérrez-Merino, J. J. G. Moura and M. Aureliano, J. Inorg. Biochem., 2006, 100, 1734-1743.

26 T. Tiago, M. Aureliano and C. Gutierrez-Merino, Biochemistry, 2004, 43, 5551-5561.

27 G. Fraqueza, L. A. E. Batista de Carvalho, M. P. M. Marques, L. Maia, C. A. Ohlin, W. H. Casey and M. Aureliano, Dalton Trans., 2012, 41, 12749-12758.

28 G. Fraqueza, C. A. Ohlin, W. H. Casey and M. Aureliano, J. Inorg. Biochem., 2012, 107, 82-89.

29 A. Amado, M. Aureliano, P. J. Ribeiro-Claro and J. TeixeiraDias, J. Raman Spectrosc., 1993, 24, 669-703.

30 E. M. Villa, C. A. Ohlin, E. Balogh, T. M. Anderson, M. D. Nyman and W. H. Casey, Angew. Chem., Int. Ed., 2008, 47, 4844-4846.

31 R. S. Tobias, Can. J. Chem., 1965, 43, 1222-1225.

32 W. P. Griffith and T. D. Wickins, J. Chem. Soc. A, 1966, 1087-1090.

33 A. Goiffon and B. Spinner, Rev. Chim. Miner., 1974, 11, 262-268.
34 J.-M. Jehng and I. E. Wachs, Chem. Mater., 1991, 3, 100-107. 35 C. A. Ohlin, E. M. Villa and W. H. Casey, Inorg. Chim. Acta, 2009, 362, 1391-1392.

36 Y. Liu, S.-X. Guo, L. Ding, C. A. Ohlin, A. M. Bond and J. Zhang, ACS Appl. Mater. Interfaces, 2015, 7, 16632-16644.

37 M. J. Frisch, et al., Gaussian 09, Gaussian, Inc., Wallingford, CT, USA, 2009.

38 J. Tomasi, B. Mennucci and R. Cammi, Chem. Rev., 2005, 105, 2999-3094.

39 K. L. Schuchardt, B. T. Didier, T. Elsethagen, L. Sun, V. Gurumoorthi, J. Chase, J. Li and T. L. Windus, J. Chem. Inf. Model., 2007, 47, 1045-1052.

40 C. A. Ohlin, E. M. Villa, J. C. Fettinger and W. H. Casey, Angew. Chem., Int. Ed., 2008, 47, 8251-8254.

41 W. G. Klemperer and K. A. Marek, Eur. J. Inorg. Chem., 2013, 1762-1771.

42 M. Matsumoto, Y. Ozawa, A. Yagasaki and Y. Zhe, Inorg. Chem., 2013, 52, 7825-7827.

43 M. K. Kershawani, B. Brauer and J. M. L. Martin, J. Phys. Chem., 2015, 119, 1701-1714.

44 I. Grenthe, A. V. Plyasunov and K. Spahiu, in Modelling in aquatic chemistry, ed. I. Grenthe and I. Puigdomenech, OECD Nuclear Energy Agency, Paris, 1997, ch. IX, pp. 325-426. 